\title{
The Impact of Organizational Creativity on Sustainable Development in the Kuwaiti Industrial Sector
}

\author{
FAISAL KHALEEFAH JASEM ALSABAH ${ }^{1}$, MOHAMMED SALEEM ALSHURA ${ }^{2}$ \\ ${ }^{1}$ The World Islamic Sciences and Education University, JORDAN \\ ${ }^{2}$ The World Islamic Sciences and Education University, JORDAN
}

\begin{abstract}
This study explored the impact of organizational creativity on sustainable development in the Kuwaiti industrial sector. The researchers adopted a descriptive-analytical approach to explore the impact of organizational creativity on sustainable development in the Kuwaiti industrial sector. The researchers designed a questionnaire to pass it to the members of the population in the Kuwaiti Industrial Sector. The population consists of all the administrators who work in the Kuwaiti Industrial sector. It was found that organizational creativity dimensions (acknowledgment, utilization, and reengineering) impact sustainable development dimensions (the economic, social, and environmental dimensions) in the Kuwaiti industrial sector. Also, it was found that there is a high level of agreement on applying Organizational Creativity and Sustainable Development in the Kuwaiti Industrial Sector. The researchers recommended examining the technological methods used in the industrial sector, managing the costs efficiently by companies, and providing the required financial and human resources for reengineering various resources.
\end{abstract}

Key-Words:- organizational creativity, sustainable development, the Kuwaiti industrial sector

Received: August 4, 2021. Revised: December 30, 2021. Accepted: January 19, 2022. Published: January 20, 2022.

\section{Introduction}

Development is deemed essential for improving the quality of citizens' lives in any country by reducing the severity of poverty. It does that through empowering the youth and letting them rely on themselves. It does that through having effective leadership.

Sustainable development is usually achieved in (economic, social, and political areas). It should be noted that it is significant to share knowledge to achieve sustainable development in those three areas. It is a three-dimensional concept, that is: Environment sustainable development emphasizes the significance of preserving environmental quality to do economic activities and preserve people's quality of life. -Socially sustainable development aims at protecting people's rights and promoting equality and preserve the cultural identities of people, as well as, show respect to cultural diversity, religions, and ethnicity. -Sustainable economic development aims to maintain the social, human, and natural capital required to have good living conditions. (Abu AZanat and Ghnaim, 2005; Gharib et al., 2018).

To achieve sustainable development, attention must be provided to all the dimensions, because it is not easy to meet the requirements needed for achieving such development. The goals of each type of development must be consistent with the goals of the other types of development to achieve a state of balance (Hawi et al.,2015).

Creativity became a significant concept. It has been playing a major role in understanding organizational planning. It has been playing a major role in improving competitiveness. That is because creativity supports organizational development and plays a major role in improving the implementation of the future vision of the organization in order to ensure survival (Hashem,2016). The challenges facing organizations forced them to show a high organizational creativity level as an integral element of their strategies. Organizations are required to know the challenges being faced in the global and local workplace environment (Rialti et al. ,2019).

Hence, there is a need to conduct this study to explore the impact of organizational creativity on sustainable development in the Kuwaiti industrial sector.

\section{The Study's Significance}

The industrial sector in the State of Kuwait is one of the most important economic sectors that contribute 
to the gross domestic product. It contributes more than half of the GDP, specifically $59.6 \%$, and employs almost a quarter of the workforce. Kuwait is keen to diversify its existing industries, despite the fact that the economy is based on oil extraction mainly, as the petroleum industry contributes $43 \%$ of the total. Kuwait's GDP as one of the main exports.

The importance of this study stems from the importance of its variables and the lack of previous studies that have been applied on this subject in the Kuwaiti industrial environment.

\section{Statement of the Problem}

The significance of sustainable development in economic sectors has been increasing significantly. The term (sustainable development) has increased much on various occasions and economic events. However, the attention provided to this term and the factors affecting it in the Kuwaiti industrial sector is not adequate (Sulphey \& Alkahtani, 2017)

Industrial companies in Kuwait have been operating in a complex dynamic environment. That forced those companies to cope with administrative, economic, and technological circumstances and respond fast to environmental changes. That shall improve the skills and capabilities of those companies and enable them to succeed. In order for those companies to adjust to the changing conditions in the environment, they must show high organizational creativity (Muslimat et al., 2020)

The problem of this study is represented in the questions below

Q.1. What is the extent of showing organizational creativity by the industrial companies in Kuwait?

Q.2. What is the extent of showing attention to sustainable development in the industrial companies in Kuwait?

Q.3 What is the impact of organizational creativity dimensions (acknowledgment, utilization, and reengineering) on sustainable development dimensions (i.e., the economic, social, and environmental dimensions) in the industrial companies in Kuwait?

\section{Study Hypotheses}

The researchers developed the following hypotheses:

\section{Main hypothesis:}

Organizational creativity dimensions do not have a significant impact -at the significance level of $a \leq 0.05$ - on sustainable development dimensions (i.e. the economic, social, and environmental dimensions) in the industrial companies in Kuwait.

\section{The sub-hypotheses}

H0.1: Organizational creativity dimensions do not have a significant impact -at the significance level of $a \leq 0.05$ - on the economic dimension of sustainability in the industrial companies in Kuwait

H0.2: Organizational creativity dimensions do not have a significant impact -at the significance level of $a \leq 0.05$ - on the social dimension of sustainability in the industrial companies in Kuwait

H0.3: Organizational creativity dimensions do not have a significant impact -at the significance level of $\mathrm{a} \leq 0.05-$ on the environmental dimension of sustainability in the industrial companies in Kuwait

\section{Theoretical Framework Organizational creativity}

In the business world, the term "Organizational creativity" was first introduced into the literature in tandem with economic uncertainties that have grown exponentially in recent years, and the issue of adaptability focusing on "the ability to move quickly towards new opportunities and adjust for volatile markets" has become critical (Günsel et al. al, 2018, 18). However, successful companies must not only seek new opportunities but must also have "the ability to exploit the value of proprietary assets and rapidly roll out existing business models"; This ability makes the meaning of alignment important, that is, organizations must not only aim to explore the future, innovate, target new customers or even revolutionary change, but also have to, at the same time, focus on existing customers, incremental innovations and evolutionary change (Úbeda-García et al, 2017, 85).

From here, it can be said that ingenuity is the ability to master aspects, adaptability and alignment, 
and as a result, organizations must balance exploration and exploitation because achieving sustainable competitive advantage occurs through ingenious and unfamiliar organizations (Bui et al, 2021, 380).

Felício et al. (2019,610); Rialti et al. $(2019,7)-$ highlighted in their studies some of the outcomes of achieving ingenuity in organizations, in which it is possible to Achieving organizational ingenuity leads to better organizational performance, long-term success and sustainable competitive advantage. On the other hand, some literature has pointed out some negative consequences of ingenuity, which is that the cost of achieving ingenuity is much higher than the cost of creating an unfamiliar system, processes and context for an organization. However, the cost of ingenuity will be higher when the organization wants to create a dual structure of conflicting activities.

There are three main dimensions for organizational creativity. Those dimension are: (acknowledgment, utilization and re-engineering):

-Acknowledgment: It refers to the ability to identify the available opportunities and realize the threats that require doing investigation for the external environmental, exploration and research operations. That shall contribute to providing new opportunities and achieving balance between central and noncentral control. The organizations that can identify the available opportunities have mechanisms for adapting with the external environment (Al Dulaimi , et al.,2020; Chermack \& Bodwell, 2010)

-Utilization: It refers to the ability of the organization to utilize new opportunities. It enables organizations to fulfil the strategic vision and work in a strategic manner. That requires having coordination between the members of the top management. It led to avoiding wrong decisions and re-arranging the organization model (Al Dulaimi, et al.,2020; Chermack \& Bodwell, 2010)

-Re-engineering: It is the key for achieving growth. It refers to making changes to have standard resources and strategic structures in accordance with the changes in the market and the techniques used in the market. The ability to re-engineer HR functions, resources, and structures is a strategic advantage. It is a significant ability that requires having effective resources (Al Dulaimi, et al.,2020; Chermack \& Bodwell, 2010)

\section{Sustainable development}

The United Nations has defined sustainability as the ability to meet the needs of the present without compromising the ability of future generations to meet their own needs, as today there are approximately 140 developing countries in the world looking for ways to meet their development needs, but with the increasing threat of climate change, efforts must be made concrete to ensure that development today does not negatively affect future generations (Rosati and Faria, 2019, 26). Salas Zapata et al $(2019,155)$ indicates that sustainability practices support aspects of health, environmental, human and economic practices, where the principle of sustainability assumes that resources are limited and must be used wisely, taking into account longterm priorities and the consequences of the ways in which resources are used. In simpler terms, sustainability is about our children, our grandchildren, and the world we are leaving (Wamsler, 2020, 8).

Since the 1990s, there has been increasing recognition among governments, organizations, consumers, investors and other stakeholders of the importance of sustainability and the impact of organizations on society and the environment, where it has been realized that focusing solely on maximizing profits without considering the interaction of a business with its operating environment, would not be a sustainable approach ( Sun et al, 2020, 19). At the same time, there has been a growing demand for environmentally friendly products and processes, for example, hybrid vehicles and - more recently - electric vehicles instead of traditional gasoline or diesel. As such, adopting a sustainable business model can be not only a challenge but also an opportunity for organizations (Elmqvist et al, 2019, 270).

Researchers made various attempts to define the term (sustainable development). It was defined by Abu Zanat and Ghnaim (2005). The term (sustainable development) may also be defined as operations carried out consciously in society in accordance with a national vision to make economic, social and structural changes that contribute to achieving sustainable development in society. Those changes contribute to achieving ongoing improvement to living conditions (Gharib et al., 2018).

Sustainable development has three dimensions (economic, social and environmental dimensions). Those dimensions are addressed below in: 
-The economic development: It suggests that the production of services and commodities meet the needs of human beings and raise people's welfare without causing harm to the surrounding environment in terms of production and consumption. It aims at preventing the wastage of natural resources as much as possible. (Abu AZanat and Ghnaim, 2005; Gharib et al., 2018).

-Social development: It suggests that all societies are in need for receiving water, educational, health care services and job opportunities. All organizations must show respect to cultural and social heritage. They must protect the workers' rights and empower people in society. They must enable people to determine their future details (Abu AZanat and Ghnaim, 2005; Gharib et al., 2018).

-Environmental development: The world has been experiencing many human and environmental disasters, such as: global warming, desertification, loss of biological variety and other environmental problems. There is a global attention shown to environmentally sustainable development details (Abu AZanat and Ghnaim, 2005; Gharib et al., 2018).

\section{The relationship between the study's variables}

Organizational creativity aims at achieving a balance between two different tasks that complement each other. Profitability and sustainability are different tasks that complement each other (Du et al., 2013). Sustainable development and profit-oriented development often have contradicted goals. Sustainability and profitability have clear contradicted goals. The behaviour that is more efficient isn't always the behaviour that is more sustainable (Du et al., 2013). Organizations often suffer from having contradictions between economic and social orientations (Shepherd et al., 2019).

Despite that, sustainable development contributes to improving the organizational competitiveness. Financial gains can be acquired through having a strategic sustainable vision. Sustainable innovations can be made in a gradual manner. The goals of organizations are usually social and economic goals rather than competiveness-related goals (Tobias et al., 2013)

The previous studies shed a light on the significance of organizational creativity. The latter creativity can predict the extent of handling the social responsibilities by companies. It allows companies to initiate effective and ethical social initiations (Aguilera et al., 2007; Hahn et al., 2016). In other words, it positively affects the organizational performance in financial and non-financial areas (Hahn et al., 2016). In addition, many utilization activities can be carried out to raise efficiency. It aims at raising profitability on the short-term level. The exploratory activities with more innovation and creativity positively affect the sustainability of institutions (Michelino et al., 2019).

\section{Methodology}

The researchers adopted a descriptive analytical approach to explore the impact of organizational creativity on sustainable development in the Kuwaiti industrial sector. They reviewed the relevant theoretical literature and previous studies, as well as, carried out a field investigation.

\section{Population}

The population consists of all the administrators who work in the Kuwaiti Industrial sector. The total industrial companies are (30) companies (https://kiukw.org/).

\section{Sample}

In order to choose the sample, 15 administrators from each company were chosen to fill the questionnaire, so the total sample was 450 administrator, 392 forms were retrieved and deemed valid for analysis.

\section{Study Tool}

In collecting its data, the study relied on the Questionnaire, which was designed and prepared by researchers after reviewing the theoretical literature and previous studies related to the subject of the study, whether available from them in periodicals, books and references. The questionnaire consisted of two parts as follows:

Part One: It includes the demographic characteristics of the study sample members, which are represented in (gender, educational qualification, and work experience)

Part Two: The second part included two parts as follows:

- The first part: it measures organizational creativity (1-15)

-The second part: It measures sustainable development through questions (16-30). 
Note that the questions were designed according to the five-point Likert scale to measure the study variables, and for the purposes of the analysis, the answers were given weights as follows:

Strongly agree: (5). agree (4). Neutral: (3). Disagree: (2). Strongly disagree: (1)

\section{Statistical Analysis}

To answer the study's questions and test the hypotheses, the relevant descriptive analytical methods were used. The relevant statistical methods were used to meet the goals of this study. They are listed below:

1)- Descriptive statistic measures: They include: means, standard deviations, relative significance, percentages, and frequencies. They are used to offer a description for the study's sample
2)- Cronbach alpha coefficient values: They are used to measure the reliability of the instrument

3)- Multiple regression analysis: They are carried out to explore the impact of the independent variable on the dependent one.

\section{Sample Characteristics}

Frequency and percent were used to describe the sample characteristics, it was found that $63.8 \%$ of the sample is males and the rest is females, also, it was found that highest percent of the sample has got bachelor degree( $63.8 \%$ ), whereas, $52.6 \%$ of the sample has experience for more than 10 years.

\section{Descriptive Analysis}

Mean and standard deviation were used to describe attitudes toward the following questions:

Table 1. Descriptive Analysis for the study questions

\begin{tabular}{|c|c|c|c|}
\hline No. & Item & Mean & Std Deviation \\
\hline \multicolumn{4}{|c|}{ Organizational creativity } \\
\hline \multicolumn{4}{|c|}{ Acknowledgment } \\
\hline 1. & $\begin{array}{l}\text { The company's management is keen on identifying the } \\
\text { available opportunities and risks in the target market. }\end{array}$ & 3.60 & 1.058 \\
\hline 2. & $\begin{array}{l}\text { An external environmental examination is carried out for } \\
\text { the targeted market in a periodical manner }\end{array}$ & 3.33 & 1.199 \\
\hline 3. & $\begin{array}{l}\text { The company's management keeps following up the } \\
\text { latest technological methods in the industrial sector }\end{array}$ & 3.90 & .901 \\
\hline 4. & $\begin{array}{l}\text { The company's management is keen on having a flexible } \\
\text { organizational structure that respond to the changes in } \\
\text { the surrounding environment }\end{array}$ & 3.85 & .923 \\
\hline 5. & $\begin{array}{l}\text { The company's management provides much attention to } \\
\text { the process of setting effective strategies to meet the } \\
\text { company's goals }\end{array}$ & 4.16 & .865 \\
\hline \multicolumn{4}{|c|}{ Utilization } \\
\hline 6. & $\begin{array}{l}\text { The company's management provides much attention to } \\
\text { providing a variety of products in the target market }\end{array}$ & 3.84 & .979 \\
\hline 7. & $\begin{array}{l}\text { The company's management is keen on managing costs } \\
\text { in the suitable manner }\end{array}$ & 4.02 & .803 \\
\hline 8. & $\begin{array}{l}\text { The company's products are development in periodical } \\
\text { manner }\end{array}$ & 4.01 & .852 \\
\hline 9. & $\begin{array}{l}\text { The company's management is keen on utilizing new } \\
\text { opportunities in the targeted market. }\end{array}$ & 4.14 & .812 \\
\hline 10. & $\begin{array}{l}\text { Much attention is provided to following up competitors } \\
\text { in the targeted market. Much attention is provided to } \\
\text { examining the competitors' market performance }\end{array}$ & 4.03 & .813 \\
\hline \multicolumn{4}{|c|}{ Re-engineering } \\
\hline 11. & The company's management has the ability to re- & 4.10 & .853 \\
\hline
\end{tabular}




\begin{tabular}{|c|c|c|c|}
\hline & $\begin{array}{l}\text { engineer strategic structures and resources in accordance } \\
\text { with the changes that occur to the market and the } \\
\text { techniques used in the market }\end{array}$ & & \\
\hline 12. & $\begin{array}{l}\text { Financial and human resources are provided in order to } \\
\text { re-engineer various resources }\end{array}$ & 4.20 & .930 \\
\hline 13. & $\begin{array}{l}\text { The company's management realizes the significance of } \\
\text { re-changing the administrators in accordance with the } \\
\text { market needs }\end{array}$ & 3.90 & 1.017 \\
\hline 14. & $\begin{array}{l}\text { The company's management realizes the significance of } \\
\text { developing the work methods }\end{array}$ & 4.07 & .913 \\
\hline 15. & $\begin{array}{l}\text { Much attention is provided to improving the company's } \\
\text { ability in the oil investment field }\end{array}$ & 3.40 & 1.210 \\
\hline \multicolumn{4}{|c|}{ Sustainable development } \\
\hline \multicolumn{4}{|c|}{ Economic dimension } \\
\hline 16. & $\begin{array}{l}\text { The company's management shows much attention to } \\
\text { meeting the annual financial goals }\end{array}$ & 3.72 & .834 \\
\hline 17. & $\begin{array}{l}\text { Much attention is provided to achieving the required } \\
\text { revenue on investment }\end{array}$ & 3.85 & .862 \\
\hline 18. & $\begin{array}{l}\text { Much attention is provided to improving the financial } \\
\text { status of the company }\end{array}$ & 3.80 & .815 \\
\hline 19. & $\begin{array}{l}\text { The company's management is keen on achieving } \\
\text { satisfactory profit for the favour of stakeholders }\end{array}$ & 4.06 & .847 \\
\hline 20. & $\begin{array}{l}\text { There is adequate liquidity that fosters the company's } \\
\text { ability to meet the emerging needs at the workplace }\end{array}$ & 4.05 & .804 \\
\hline \multicolumn{4}{|c|}{ Social dimension } \\
\hline 21. & $\begin{array}{l}\text { There is attention to the process of fostering social } \\
\text { development in the local environment }\end{array}$ & 3.80 & .984 \\
\hline 22. & $\begin{array}{l}\text { The company's management is keen on achieving a } \\
\text { balance between its needs and the needs of its customers }\end{array}$ & 3.99 & .820 \\
\hline 23. & $\begin{array}{l}\text { The company's management is keen on serving the local } \\
\text { community }\end{array}$ & 4.07 & .817 \\
\hline 24. & $\begin{array}{l}\text { The company's management is keen on assigning } \\
\text { functions for the ones residing in the local community }\end{array}$ & 4.00 & .924 \\
\hline 25. & $\begin{array}{l}\text { The company offers effective solutions that are } \\
\text { beneficial for the environment in the local community }\end{array}$ & 4.18 & .652 \\
\hline \multicolumn{4}{|c|}{ Environmental dimension } \\
\hline 26. & The company is keen to utilize resources optimally & 4.23 & .604 \\
\hline 27. & $\begin{array}{l}\text { The company's management is keen on reducing the } \\
\text { wastage that is harmful to the environment to the least } \\
\text { possible level }\end{array}$ & 3.77 & .983 \\
\hline 28. & The available power is used fully & 3.94 & .923 \\
\hline 29. & $\begin{array}{l}\text { The company's management is keen on reducing the } \\
\text { risks associated with work to the minimum level }\end{array}$ & 3.60 & 1.039 \\
\hline 30 . & $\begin{array}{l}\text { The company's management is keen on providing } \\
\text { adequate insurance coverage }\end{array}$ & 4.06 & .859 \\
\hline
\end{tabular}

Above Table shows that there are positive attitudes toward above questions, since their means are greater than mean of the scale (3).
As for Organizational creativity variable, it is found that

-Acknowledgment: Q6(The company's management provides much attention to the process of setting 
effective strategies to meet the company's goals) has the highest mean whereas Q2(An external environmental examination is carried out for the targeted market in a periodical manner) has the lowest mean

-Utilization: Q9(The company's management is keen on utilizing new opportunities in the targeted market.) has the highest mean whereas Q6(The company's management provides much attention to providing a variety of products in the target market) has the lowest mean

-Re-engineering: Q12(Financial and human resources are provided in order to re-engineer various resources) has the highest mean whereas Q13(The company's management realizes the significance of re-changing the administrators in accordance with the market needs) has the lowest mean

As for Sustainable development variable, it is found that:

-Economic dimension: Q19(The company's management is keen on achieving satisfactory profit for the favour of stakeholders) has the highest mean whereas Q16(The company's management shows much attention to meeting the annual financial goals) has the lowest mean

-Social dimension: Q25(The company offers effective solutions that are beneficial for the environment in the local community) has the highest mean whereas Q21(There is attention to the process of fostering social development in the local environment) has the lowest mean

-Environmental dimension: Q26(The company is keen to utilize resources optimally) has the highest mean whereas Q29(The company's management is keen on reducing the risks associated with work to the minimum level ) has the lowest mean

Table (2) summarizes the results toward the study variables. It shows that there are positive attitudes toward each variable, since its mean is greater than mean of the scale (3).

Table 2. Escriptive Analysis for the study variables

\begin{tabular}{lrrrrr}
\multicolumn{5}{c}{ Descriptive Statistics } \\
\hline \hline & $\mathrm{N}$ & Minimum & Maximum & Mean & Std. Deviation \\
\hline Acknowledgment & 392 & 1.60 & 5.00 & 3.7694 & .75749 \\
Utilization & 392 & 1.80 & 5.00 & 4.0122 & .64800 \\
Re_engineering & 392 & 2.00 & 5.00 & 3.9337 & .67871 \\
Sustainable & 392 & 2.80 & 5.00 & 3.9423 & .55530 \\
Economic & 392 & 2.80 & 5.00 & 3.8974 & .61457 \\
Social & 392 & 2.40 & 5.00 & 4.0097 & .60687 \\
Environmental & 392 & 2.20 & 5.00 & 3.9199 & .65253
\end{tabular}

\section{Reliability Test}

Cronbach Alpha was used to test the consistency of the questionnaire, it was found that $\alpha=0.941$ reflects high level of reliability since it is greater than accepted percent 0.60 (Sekaran \& Bougie, 2010)

\section{Hypotheses Testing}

Main hypothesis:

Organizational creativity dimensions don't have a significant impact -at the significance level of $\mathrm{a} \leq 0.05$ - on sustainable development dimensions (i.e. the economic, social, and environmental dimensions) in the industrial companies in Kuwait.

Table 3. Main hypothesis testing

\begin{tabular}{llrrrrrrr}
\hline \hline Model & & Sum of & & & & & R & R Square \\
\hline 1 & Regression & Squares & df & Mean Square & F & Sig. & & \\
& Residual & 61.544 & 3 & 20.515 & 134.855 & $.000^{\mathrm{b}}$ & 0.714 & 0.509 \\
& Total & 59.024 & 388 & .152 & & & & \\
& 120.568 & 391 & & & & & \\
\hline \hline
\end{tabular}




\section{Coefficients}

\begin{tabular}{|c|c|c|c|c|c|c|}
\hline \multirow{2}{*}{\multicolumn{2}{|c|}{ Model }} & \multicolumn{2}{|c|}{ Unstandardized Coefficients } & \multirow{2}{*}{$\begin{array}{c}\begin{array}{c}\text { Standardized } \\
\text { Coefficients }\end{array} \\
\text { Beta }\end{array}$} & \multirow[b]{2}{*}{$\mathrm{t}$} & \multirow[b]{2}{*}{ Sig. } \\
\hline & & $\mathrm{B}$ & Std. Error & & & \\
\hline \multirow[t]{4}{*}{1} & (Constant) & 1.518 & .126 & & 12.065 & .000 \\
\hline & Acknowledgment & .093 & .042 & .127 & 2.236 & .026 \\
\hline & Utilization & .132 & .061 & .154 & 2.171 & .031 \\
\hline & Re_engineering & .392 & .054 & .479 & 7.291 & .000 \\
\hline
\end{tabular}

Multiple Regression was used to test above hypothesis. Above table shows that $\mathrm{F}$ value $=134.855$ is significant at 0.05 , that mean organizational creativity dimensions have a significant impact -at the significance level of $a \leq 0.05$ - on sustainable development dimensions (i.e. the economic, social, and environmental dimensions) in the industrial companies in Kuwait. In the coefficients table it is found that $t$ value for each variable is significant at 0.05 level. Also, it was found that $r=0.714$ reflects high level of correlation and the independent variables explain $50.9 \%$ of the variance in the dependent variable.

\section{The sub-hypotheses}

H0.1: Organizational creativity dimensions don't have a significant impact -at the significance level of $\mathbf{a} \leq \mathbf{0 . 0 5 -}$ on the economic dimension of sustainable in the industrial companies in Kuwait.

Table 4. H0.1 testing

\begin{tabular}{|c|c|c|c|c|c|c|c|c|}
\hline Model & & $\begin{array}{c}\text { Sum of } \\
\text { Squares }\end{array}$ & $\mathrm{df}$ & Mean Square & $\mathrm{F}$ & Sig. & $\mathrm{R}$ & R Square \\
\hline \multirow[t]{3}{*}{1} & Regression & 61.085 & 3 & 20.362 & 91.235 & $.000^{\mathrm{b}}$ & 0.643 & 0.414 \\
\hline & Residual & 86.593 & 388 & .223 & & & & \\
\hline & Total & 147.677 & 391 & & & & & \\
\hline
\end{tabular}

\section{Coefficients $^{\mathrm{a}}$}

\begin{tabular}{|c|c|c|c|c|c|c|}
\hline \multirow{2}{*}{\multicolumn{2}{|c|}{ Model }} & \multicolumn{2}{|c|}{ Unstandardized Coefficients } & \multirow{2}{*}{$\begin{array}{c}\begin{array}{c}\text { Standardized } \\
\text { Coefficients }\end{array} \\
\text { Beta }\end{array}$} & \multirow[b]{2}{*}{$\mathrm{t}$} & \multirow[b]{2}{*}{ Sig. } \\
\hline & & $\mathrm{B}$ & Std. Error & & & \\
\hline 1 & (Constant) & 1.407 & .152 & & 9.231 & .000 \\
\hline & Acknowledgment & .011 & .051 & .013 & .212 & .832 \\
\hline & Utilization & .433 & .074 & .456 & 5.874 & .000 \\
\hline & $\mathrm{Re}$ engineering & .181 & .065 & .200 & 2.783 & .006 \\
\hline
\end{tabular}

Multiple Regression was used to test above hypothesis. Above table shows that $\mathrm{F}$ value $=91.235$ is significant at 0.05 , that mean organizational creativity dimensions have a significant impact -at the significance level of $a \leq 0.05$ - on the economic dimension of sustainable in the industrial companies in Kuwait. In the coefficients table it is found that $t$ value for each variable is significant at 0.05 level except (acknowledgement variable). Also, it was found that $r=0.643$ reflects high level of correlation and the independent variables explain $41.4 \%$ of the variance in the dependent variable.

H0.2: Organizational creativity dimensions don't have a significant impact -at the significance level of $\mathbf{a} \leq \mathbf{0 . 0 5}$ - on the social dimension of sustainable in the industrial companies in Kuwait. 
Table 5. H0.2 testing

\begin{tabular}{|c|c|c|c|c|c|c|c|c|}
\hline Model & & $\begin{array}{l}\text { Sum of } \\
\text { Squares }\end{array}$ & $\mathrm{df}$ & Mean Square & $\mathrm{F}$ & Sig. & $\mathrm{R}$ & R Square \\
\hline \multirow[t]{3}{*}{1} & Regression & 54.058 & 3 & 18.019 & 77.731 & $.000^{\mathrm{b}}$ & 0.613 & 0.375 \\
\hline & Residual & 89.945 & 388 & .232 & & & & \\
\hline & Total & 144.003 & 391 & & & & & \\
\hline
\end{tabular}

\section{Coefficients}

\begin{tabular}{|c|c|c|c|c|c|c|}
\hline \multirow[b]{2}{*}{ Mode } & & \multicolumn{2}{|c|}{ Unstandardized Coefficients } & $\begin{array}{c}\text { Standardized } \\
\text { Coefficients }\end{array}$ & \multirow[b]{2}{*}{$\mathrm{t}$} & \multirow[b]{2}{*}{ Sig. } \\
\hline & & $\mathrm{B}$ & Std. Error & Beta & & \\
\hline \multirow[t]{4}{*}{1} & (Constant) & 1.724 & .155 & & 11.096 & .000 \\
\hline & Acknowledgment & .125 & .052 & .155 & 2.417 & .016 \\
\hline & Utilization & .159 & .075 & .170 & 2.118 & .035 \\
\hline & $\mathrm{Re}$ engineering & .299 & .066 & .335 & 4.512 & .000 \\
\hline
\end{tabular}

Multiple Regression was used to test above hypothesis. Above table shows that $\mathrm{F}$ value $=77.731$ is significant at 0.05 , that mean organizational creativity dimensions have a significant impact -at the significance level of $a \leq 0.05-$ on the social dimension of sustainable in the industrial companies in Kuwait. In the coefficients table it is found that $t$ value for each variable is significant at 0.05 level.Also, it was found that $r=0.613$ reflects high level of correlation and the independent variables explain $37.5 \%$ of the variance in the dependent variable.

H0.3: Organizational creativity dimensions don't have a significant impact -at the significance level of $\mathbf{a} \leq \mathbf{0 . 0 5}$ - on the environmental dimension of sustainable in the industrial companies in Kuwait

Table 6. H0.3 testing

\begin{tabular}{|c|c|c|c|c|c|c|c|c|}
\hline Model & & $\begin{array}{c}\text { Sum of } \\
\text { Squares }\end{array}$ & $\mathrm{df}$ & Mean Square & $\mathrm{F}$ & Sig. & $\mathrm{R}$ & R Square \\
\hline \multirow[t]{3}{*}{1} & Regression & 79.991 & 3 & 26.664 & 119.608 & .000 & 0.693 & 0.48 \\
\hline & Residual & 86.494 & 388 & .223 & & & & \\
\hline & Total & 166.485 & 391 & & & & & \\
\hline
\end{tabular}

Coefficients

\begin{tabular}{|c|c|c|c|c|c|c|}
\hline \multirow[b]{2}{*}{ Model } & & \multicolumn{2}{|c|}{ Unstandardized Coefficients } & $\begin{array}{l}\text { Standardized } \\
\text { Coefficients }\end{array}$ & \multirow[b]{2}{*}{$\mathrm{t}$} & \multirow[b]{2}{*}{ Sig. } \\
\hline & & B & Std. Error & Beta & & \\
\hline \multirow[t]{4}{*}{1} & (Constant) & 1.424 & .152 & & 9.349 & .000 \\
\hline & Acknowledgment & .145 & .051 & .168 & 2.863 & .004 \\
\hline & Utilization & -.196 & .074 & -.194 & -2.656 & .008 \\
\hline & $\mathrm{Re}$ engineering & .695 & .065 & .723 & 10.684 & .000 \\
\hline
\end{tabular}

Multiple Regression was used to test above hypothesis. Above table shows that $F$ value $=119.608$ is significant at 0.05 , that mean organizational creativity dimensions have a significant impact -at 
the significance level of $a \leq 0.05-$ on the environmental dimension of sustainable in the industrial companies in Kuwait. In the coefficients table it is found that $t$ value for each variable is significant at 0.05 level. Also, it was found that $r$ $=0.693$ reflects high level of correlation and the independent variables explain $48 \%$ of the variance in the dependent variable.

\section{Results and Conclusion}

This study explored the impact of organizational creativity on sustainable development in the Kuwaiti industrial sector. The researchers adopted a descriptive-analytical approach to explore the impact of organizational creativity on sustainable development in the Kuwaiti industrial sector. There is no doubt that sustainability contributes to raising the organizational creativity level. This article contributes to promoting knowledge among people about the role of creativity in achieving sustainability. There is a need for doing a further investigation for identifying the relationship between organizational creativity and sustainable development. That shall enable organizations to handle the challenges in the competitive market and improve their competitiveness. It shall contribute to facilitating the process of designing strategies that aim at attracting consumers. It shall contribute to facilitating the process of implementing effective strategies that contribute to attracting and retaining customers and employees. It shall contribute to offering visions about the way of reducing costs and making reforms. In addition, investigating sustainability and its relationship with organizational creativity shall contribute to improving the decisionmaking process. It shall contribute to meeting the interest of stakeholders. The researchers found that organizational creativity dimensions (acknowledgment, utilization, and reengineering) impact sustainable development dimensions (the economic, social, and environmental dimensions) in the Kuwaiti industrial sector. Also, it was found that there is a high level of agreement on applying Organizational Creativity and Sustainable Development in the Kuwaiti Industrial Sector. The latter results are in agreement with the one reached by Du et al. (2013); Shepherd et al. (2019), Tobias et al. (2013), Hahn et al. (2016) and Michelino et al. (2019).

\section{Recommendations}

The researchers recommend:

- Following up the information related to the latest technological methods used in the industrial sector

- Ensuring that the cost management in companies are efficient

- Providing the requires financial and human resources that enable companies to re-engineer their resources

- Providing attention to setting the plans that aim at improving the financial situation of companies

- Providing the ones residing in the local community with job opportunities

- Reducing the amount of wastage that cause harm to the environment to the least possible level

- Reducing the risks associated with work to the least possible level

\section{References:}

[1] Abu Zanat, M.; and Ghnaim, O. (2005). Sustainable development: A theoretical study on concept and content. Al-Manarah, 12(1), 149-172

[2] Abu Zyadah, Z. (2020). The role of talent management practices in promotingbetween organizational creativity: An empirical study targeting Al-Jawal Telecommunication $\mathrm{Co}$ in Palestine. Ajman Journal for studies and research. 18(2), 3-39

[3] Aguilera, R. V., Rupp, D. E., Williams, C. A., \& Ganapathi, J. (2007). Putting the s back in corporate social responsibility: A multilevel theory of social change in organizations. Academy of Management Review, 32, 836-863. https://doi.org/10.2307/20159338.

[4] Al Dulaimi , A., Younis,J. \& Daya,H. (2020). The Role of Strategic Prowess in Promoting High Compliance Management-A Sample of the Directors of The Iraqi Media Network. Research in Economics and Management,5(4),92-114 $.10 .22158 /$ rem.v5n4p92

[5] Al-Hasan, A. (2011). Sustainable development and the requirements of achieving it. A study submitted to a conference titled (the government strategy in fighting against unemployment and achieving sustainable development. Al-Masilah University. Algeria

[6] Chermack, T. J., \& Bodwell, W. (2010). Organizational Ambidexterity: Integrating Deliberate And Emergent Strategy With Scenario Planning. Technological Forecasting \& Social Change, 77, 193-202.

https://doi.org/10.1016/j.techfore.2009.07.004 
[7] Du, W., Pan, S. L., \& Zuo, M. (2013). How to balance sustainability and profitability in technology organizations: An ambidextrous perspective. IEEE Transactions on Engineering Management, 60(2), 366-385. https://doi.org/10.1109/TEM.2012. 2206113

[8] Elmqvist, T., Andersson, E., Frantzeskaki, N., McPhearson, T., Olsson, P., Gaffney, O., ... \& Folke, C. (2019). Sustainability and resilience for transformation in the urban century. Nature sustainability, 2(4), 267-273.

[9] Felício, J. A., Caldeirinha, V., \& Dutra, A. (2019). Ambidextrous capacity in small and medium-sized enterprises. Journal of Business Research, 101, 607614.

[10] Gharib ,M., Allil, K. ,Durrah, O. and Suttof, M. (2018). Impact of Sustainable Development on Financial Performance, International Journal of Management and Applied Science,4(10), 22-26

[11] Günsel, A., Altındağ, E., Keçeli, S. K., Kitapçı, H., \& Hizıroğlu, M. (2018). Antecedents and consequences of organizational ambidexterity: The moderating role of networking. Kybernetes.

[12] Hahn, T., Pinske, J., \& Preuss, L. (2016). Ambidexterity for corporate social performance. Organization Studies, 37(2), 213-235. https://doi.org/10.1177/0170840615604506

[13] Hashem, T. (2016). Commercial Banks Use of Decision Support System to Achieve Marketing Creativity. International Review of Management and Business Research, 5(3), 1059-1067

[14] Hawi, R. , Alkhodary,D. \& Hashem, T. (2015). Managerial Competencies and Organizations Performance. International Journal of Management Sciences,5(11), 723-735

[15] Michelino, F., Cammarano, A., Celone, A., \& Caputo, M. (2019). The linkage between sustainability and innovation performance in IT hardware sector. Sustainability, 11(16), 4275. https://doi:10.3390/su11164275.

[16] Muslimat,A. , Hariyaty, A., Erlangga,H., Sarwani, Purwanto,A. \& Sunarsi, D. (2020). Effect of Organizational Commitment on the Sustainability Performance of INDONESIAN Industries, Palarch's Journal Of Archaeology Of Egypt/Egyptology 17(6). 8330-8347

[17] Rialti, R., \& Marzi, G. (2019). Ambidextrous organizations in the big data era: The role of information systems. Springer Nature.

[18] Rosati, F., \& Faria, L. G. (2019). Addressing the SDGs in sustainability reports: The relationship with institutional factors. Journal of cleaner production, 215, 1312-1326.

[19] Salas Zapata, W. A., \& Ortiz Muñoz, S. M. (2019). Analysis of meanings of the concept of sustainability. Sustainable Development, 27(1), 153161.

[20] Sekaran, U. \& Bougie, R. (2010). Research methods for business: A skill building approach. John Wiley $\&$ Sons.

[21] Shepherd, D. A., Williams, T. A., \& Zhao, E. Y. (2019). A framework for exploring the degree of hybridity in entrepreneurship. Academy of Management Perspectives, (published online). https://doi.org/10.5462/amp.2018.0013

[22] Sulphey M.M., Alkahtani N.S., (2017). Organizational ambidexterity as a prelude to corporate sustainability, "Journal of Security and Sustainability Issues", $7(2), 335-347 \quad$.DOI: 10.9770/jssi.2017.7.2(13)

[23] Sun, H., Mohsin, M., Alharthi, M., \& Abbas, Q. (2020). Measuring environmental sustainability performance of South Asia. Journal of Cleaner Production, 251, 119519.

[24] Tobias, J. M., Mair, J., \& Barbosa-Leiker, C. (2013). Toward a theory of transformative entrepreneuring: Poverty reduction and conflict resolution in Rwanda's entrepreneurial coffee sector. Journal of Business Venturing, 28(6), 728-742. https://doi. org/10.1016/j.jbusvent.2013.03.003

[25] Úbeda-García, M., Claver-Cortés, E., Marco-Lajara, B., \& Zaragoza-Sáez, P. (2017). Human resource flexibility and performance in the hotel industry: The role of organizational ambidexterity. Personnel Review 46(4),824-846

[26] Wamsler, C. (2020). Education for sustainability: Fostering a more conscious society and transformation towards sustainability. International Journal of Sustainability in Higher Education.

\section{Creative Commons Attribution License 4.0 (Attribution 4.0 International, CC BY 4.0)}

This article is published under the terms of the Creative Commons Attribution License 4.0 https://creativecommons.org/licenses/by/4.0/deed.en US 